\title{
Cultural History and its Neighbours
}

\author{
Peter Burke \\ Emmanuel College, University of Cambridge, United Kingdom \\ e-mail: upb1000@cam.ac.uk
}

Received: 26 March 2012; Accepted: 16 April 2012; Published online: 15 May 2012

\begin{abstract}
This article offers a kind of map of intellectual fields that are more or less close to cultural history. It is difficult to separate cultural history from intellectual, social and political history, from archaeology and from the histories of such activities as art, literature, language and religion, whether these histories are studied in departments of history or under the umbrella of "visual studies", "religious studies" or "cultural studies". All these neighbours form an "inner circle", discussed in relative detail. Beyond it lies a "middle circle" of disciplines that are separate from cultural history but have made considerable impact on it: anthropology, ethnology, sociology, politics and geography. Still further away, and discovered by cultural historians only recently, comes an "outer circle", comprising psychology, cognitive studies, neuroscience and biology. The effect of the outer circle of disciplines on the practice of cultural history remains uncertain.
\end{abstract}

KEYWORDS: disciplines; interdisciplinarity; turns; cultural studies.

Citation / Cómo citar este artículo: Burke, P. (2012) "Cultural History and its Neighbours". Culture \& History Digital Journal 1(1): e006. doi: http://dx.doi.org/10.3989/chdj.2012.006

RESUMEN: La Historia cultural y sus vecinos.- Este artículo ofrece un cierto mapa de campos intelectuales más o menos cercano a la historia cultural. Es difícil separar la historia cultural de la intelectual, social o política, de la arqueología y de historias de actividades como arte, literatura, lenguaje y religión, tanto si estas historias se estudian en departamentos de historia como si caen bajo el paraguas de "estudios visuales", "estudios religiosos" o "estudios culturales". Todos estos vecinos constituyen un "círculo interior" que se discute con cierto detalle. Mas allá se sitúa un "círculo medio" de disciplinas que están separadas de la historia cultural, pero han tenido considerable impacto sobre ella: antropología, etnología, sociología, politología y geografía. Y un paso más allá, según han descubierto solo de manera reciente los historiadores culturales, existe un "círculo exterior", que comprende psicología, estudios cognitivos, neurociencia y biología. El efecto de estas disciplinas exteriores sobre la práctica de la historia cultural nos es desconocido.

PALABRAS CLAVE: disciplinas; giros interdisciplinarios; estudios culturales

Copyright: (C) 2012 CSIC. This is an open-access article distributed under the terms of the Creative Commons Attribution-Non Commercial (by-nc) Spain 3.0 License. 


\section{THE CULTURAL TURN}

Cultural history is much older than the muchdiscussed "cultural turn" of the 1980s and 1990s. It was already practised in Germany under that name (Kulturgeschichte) as far back as the late eighteenth century, while Jacob Burckhardt's masterpiece on the Italian Renaissance, Kultur der Renaissance in Italien, was first published in 1860 (Burckhardt, 1860). In the Netherlands, which was still strongly influenced by German culture at that time, Johan Huizinga's reflections on "the task of cultural history" were given in the form of a lecture in 1926 and published soon afterwards (Huizinga, 1929). In the USA, a book entitled The Cultural Approach to History was published by the American Historical Association in 1940 (Ware, 1940). In France, by contrast, historians from François Guizot in the 1820s to Fernand Braudel in the 1970s preferred the term civilisation, while British scholars (with rare exceptions such as Arnold Toynbee) were more interested in social than in cultural history (Burke, 2008).

In other words, the cultural turn is a revival rather than a creation ex nihilo. Scholars in the USA, such as Schorske (1979), Darnton (1984) and Hunt (1984) have been in the vanguard, but this time French and British scholars have played an important part. In France, where the phrase histoire culturelle is replacing civilisation (though the history of the book remains known as l'histoire et civilisation du livre) one thinks not only of Chartier (1988), but also of specialists on the twentieth century such as Rioux and Sirinelli (1997-98). In Britain, chairs and departments in the subject have been founded at the University of Aberdeen, for instance, at Manchester and at York.

As is usually the case with revivals, cultural history has been re-invented. The definition has widened to include popular culture (although this concept is contested), and also everyday life: the history of material culture, the history of the body, the history of practices such as gestures, humour, collecting, travel and so on (Bremmer and Roodenburg, 1991, 1997; Elsner and Cardinal, 1994; Elsner and Rubiés, 1999). The contrast with earlier cultural historians was great enough to encourage the rise of the phrase "new cultural history" (Hunt, 1989) -by now no longer new. From the 1990s onwards, historians in the Englishspeaking world showed themselves to be increasingly at ease with phrases such as "the culture of retribution" (Beik, 1997); "the culture of gambling" (Kavanagh, 1993); "the culture of politeness", (Klein, 1994); "the culture of secrecy" (Vincent, 1998; Snyder, 2009) and so on.

It is obvious enough that this major shift in the discipline of history is linked to a wider cultural turn. Outside the academic domain, the increas- ingly common use of the term "culture" to refer to domains as different as business ("corporate culture"), violence ("gun culture") sex, religion and drugs reveals a change in the way in which the everyday world is perceived, a turn that has been encouraged by the political debates over "multiculturalism". Inside the university, the cultural turn has affected a whole range of disciplines, the "neighbours" with which this article is concerned.

One way of defining identity, perhaps the main way, is against the other, most obviously against the neighbours (whether they are perceived as good or bad neighbours). This form of definition works for disciplines as well as nations, groups or individuals. Sociologists have noted that claims to territory are common in the academic world (Becher and Trowler, 2005). Intellectual "fields" have to be defended from encroachment by what the great interdisciplinary scholar Aby Warburg called the intellectual "frontier police" (Grenzwachertum).

On the positive side, intellectual frontiers, like geographical ones, may be viewed as "contact zones" in which exchanges take place. Borrowing from the neighbours is a common practice for disciplines as well as for families. It may be useful to divide these neighbours into three groups or concentric circles, according to their distance from cultural history, which for the purpose of this article will be viewed as a planet surrounded by satellites (needless to say, any discipline may be placed in the centre for this purpose).

\section{THE INNER CIRCLE}

In the case of cultural history, the inner circle consists of different kinds of history: intellectual history, social history, political history, the history of science, the history of art, the history of literature, the history of the book, the history of language and the history of religion, together with classics, archaeology and the new discipline or bundle of disciplines that goes under the name of "cultural studies". From the administrative point of view, some of these varieties of history (notably art history, literature and the history of science) might be called disciplines because they have their own departments in the university, while others are sub-disciplines in the sense of being only semiautonomous. They are more likely to have their own journals and associations than to be organized in independent departments.

Intellectual History, otherwise known, especially in the United States, as the history of ideas, and including the history of philosophy (Akehurst, 2010), is particularly close to cultural history. Indeed, in its traditional German form of Geistesgeschichte it was difficult to distinguish from cultural history. One might say that cultural 
history, whose practitioners are now concerned with matter ("material culture") as well as "spirit" or ideas, includes intellectual history. Sociologically speaking, however, the two groups of scholars are separate. Departments of intellectual history are relatively unusual but programmes in intellectual history for graduate students are quite common and the approach is supported by journals such as the Journal of the History of Ideas (founded in 1940) and Modern Intellectual History (founded in 2004).

This field, approach or sub-discipline -it is difficult to say which description is more accurateis most important in the Anglophone world, from Scotland to Australia. Its principal competitor, especially in Germany and Scandinavia, is Begriffsgeschichte, the "history of concepts'. The leading figure in this approach, concerned to examine the changing uses of concepts and to place them in a wider linguistic field, was the late Reinhart Koselleck, while its monument is the nine-volume Geschichtliche Grundbegriffe (Brunner et al., 1972-97). In Spain, Fernández Sebastián (2011), a specialist on political thought, both practices and preaches conceptual history. Both intellectual and conceptual history have been affected by the cultural turn, as scholars increasingly concern themselves with what might be called "the cultural history of intellectual practices" (Burke, 2011; cf. Blake, 2008).

The relation between cultural history and social history is still more difficult to characterize (Sewell, 2005; Glickman, 2008). A generation ago, the situation was clearer. Social historians were concerned above all with social structures and they often used quantitative methods that allied them with economic historians. In some places, especially in Germany (Mergel and Welskopp, 1997), there were debates and conflicts between social and cultural historians. However, as social historians turned towards the experience of social change and cultural historians turned towards everyday practice, the two sub-disciplines have become more and more difficult to distinguish from each other. As Chartier (1989) put it in a famous epigram, we have moved "from the social history of culture to the cultural history of society".

More recently a similar rapprochement has taken place between cultural historians and political historians, who were once the most traditional members of the profession, concerned with events, "great men" and the government's point of view (Freeman, 2008). In the wake of scholars in departments of politics, political historians discovered "political culture" in the sense of the attitudes and values that underlie political action (Chicangana-Bayona and Ortega Martínez, 2011). They now study "parliamentary culture", for example (Mergel, 2002). On the other side, cultural historians have become increasingly interested in the politics of culture, including public patronage of the arts (Poirrier, 2000; Hoock, 2003). Law (Wormald, 1999) and diplomacy (Rosen, 1980; Mösslang and Riotte, 2008) are also discussed by some scholars from a cultural point of view, while a number of military historians have made their cultural turn and study topics such as "the Great War in European cultural history" (Winter, 1995).

The history of science used to be a form of intellectual history, although generally pursued in autonomous academic departments or jointly with the philosophy of science. Recently, however, a growing number of scholars in this field have made a social or a cultural turn -once again, it is difficult to distinguish the two (Dear, 1995). Examples of the concern with "scientific cultures" include a study of the "social history of truth", focussed on seventeenth-century England, and a cultural history of science in China (Shapin, 1994; Elman, 2006),

In similar fashion, art history, generally pursued in autonomous departments, has gone through both a social and a cultural phase. Studies of "art and society", often written by Marxists, have been succeeded by studies of "visual culture" (Flor, 2009). Classic studies of this kind have examined the formation of the "period eye", a way of looking specific to the Italian Renaissance (Baxandall, 1972) as well as trying to explain the emphasis on pictorial description in seventeenth-century Dutch art (Alpers, 1983). Visual culture studies spread quickly in the 1990s, leading to the foundation or renaming of departments at the expense of traditional art history. At the same time the idea of "art", especially in non-western cultures (or in the case of Europe, before the Renaissance), was being challenged (Belting, 1990). Art history was being reconceptualized as the history of images, following a minority tradition that went back to the early twentieth century but seemed to be becoming dominant a century later (Bryson et al., 1994; Woodfield, 2001). Some art historians go so far as to define themselves as cultural historians with a special interest in images. The politics and the power of images have attracted particular attention (Zanker, 1987; Warnke, 1992).

The history of literature has generally been studied in academic departments that are also concerned with literary criticism, with the critics tending to look down on the historians. It was in reaction against this devaluation of history that the North American movement known as the "New Historicism" arose in the 1980s. Its leaders, such as Greenblatt (2010), have drawn on cultural history and cultural theory in order to replace literature in its original contexts. In the process, as in the case of art history, they have sometimes defined themselves as cultural historians and moved from a history of literature in the precise sense to a broader concern 
with writing, women's writing in particular (an Anglophone journal is devoted to this subject).

As the field of literary history has widened, "plain" or "general" historians have entered it, discussing, for instance, the relation between literature and politics (Sharpe, 1987; Jouhaud, 2000). The former gap between the history of literature and the history of literacy has closed, thanks to increasing interest in what is known in romance languages as culture écrite, cultura scritta (Petrucci, 1986) or cultura escrita (Castillo Gómez, 2001). The history of the book or book culture (or as the French say, civilisation du livre), originally studied by bibliographers, librarians and some general historians, has moved towards a history of reading and welcomed specialists in literature on board (Martin, 1999; MacKenzie, 1986; Chartier, 1996; Infantes et al., 2003).

The history of language has traditionally been left more or less to the linguists and it used to be written in an essentially internalist manner. However, the rise of sociolinguistics has encouraged some historians as well as some linguists to join the social to the historical approach and to undertake what is variously known as "socio-historical linguistics" or the social or cultural history of language (Burke and Porter, 1987; Bailey, 1991; García Bourrellier and Usunáriz, 2006). In a famous phrase coined by a leading linguist, they are concerned with "who speaks what language to whom and when?'” (Fishman, 1965), in other words with the varieties of language employed by different kinds of people or in different social settings and the rules (usually unconscious) for "switching" between these varieties. What might be called the political history of language has also been explored, especially in the context of empire (Fabian, 1986; Elliott, 1994).

The history of religion, on the other hand, has often been written by historians as well as by their colleagues in what used to be known as faculties of theology and are more often described today as departments of "religious studies". In both groups the way in which this history has been written has changed very greatly in the last generation or so. It used to focus on ecclesiastical institutions (especially in the case of Christianity) and on theology, in other words the ideas of the clergy, viewed from the top down. Today, in contrast, increasing emphasis is placed on religious practice, religious experience and the more or less consciously-formulated ideas of the laity, viewed from the bottom up. Scholars have become less inclined to view religious conversion as a passive acceptance of new ideas, and more willing to regard the converts as actively reshaping their new religion (Gruzinski, 1988; Bennassar and Bennassar, 1989; Vainfas, 1995; Higashibaba, 2001). In short, the emphasis has shifted from churches to "religious cultures" (Davis, 1982; Cholvy and Hilaire, 1985-88; Schmidt, 2008).

The inner circle of neighbours also includes classics, a discipline that has long been concerned not only with ancient history but also with ancient philosophy, literature, science and art. A number of classicists, mainly but not entirely from the younger generation, are in touch with, or even part of the new cultural history. For example, the linked topics of the body, sex and gender have attracted considerable interest, following the publication of two volumes by Foucault (1984a, 1984b). One historian of ancient Greece has studied these topics through texts and presented his analysis as a form of historical anthropology (Winkler, 1990), while another has based his analysis on the evidence of art (Stewart, 1997).

Classical archaeology is one of the oldest forms of archaeology, another discipline that is close to cultural history. The paradox of the relation between archaeology and history is that although both disciplines study the human past, they have long been more remote from each other than history has been from anthropology or sociology. One group of scholars wrote history, based on written documents, while the other wrote "prehistory", based on the evidence of material culture. However, the two disciplines have been converging. Historians have discovered the evidential value of material culture, while some archaeologists have moved into later periods, including the Middle Ages and the Industrial Revolution. Some archaeologists now concern themselves with immaterial culture, especially with language (treated as evidence for events in prehistoric times) and with "the study of past ways of thought as inferred from material remains", an approach known as "cognitive archaeology" (Renfrew, 1987; Renfrew and Zubrow, 1994). At least a few members of the profession are aware of current debates among cultural historians, including discussions of hermeneutics (Hodder, 1986), while one of them has gone so far as to argue that "Archaeology is cultural history or it is nothing" (Morris, 2000: 3).

Classics may be regarded as an interdisciplinary package, the cultural studies of the ancient world. Cultural Studies has itself enjoyed a rapid rise and an equally rapid institutionalization from the 1960s onwards (Easthope, 1991; Gibson, 2009). It has taken somewhat different forms in different countries (or cultures), but in many places a key role was played by teachers of literature: Raymond Williams in Britain, for instance, Raymond Barthes in France, Stephen Greenblatt, discussed above, in the USA and Beatriz Sarlo in Argentina, all of whom place famous literary works in the context of the culture of their time and break down the wall between the "canon" of literary classics and popular culture (Irimia and Ivana, 2009). In 
this enterprise they were joined by sociologists and anthropologists such as Edgar Morin, Stuart Hall and Nestor Canclini, who provided an important injection of theory. Historians entered the movement relatively late and as a result, history is often absent from the interdisciplinary package. In the discourse of cultural studies the term "archaeology" often occurs, following Foucault, but in practice the programmes often provide little space for anything but the relatively recent past. Anglophone academics working in cultural studies are often unaware of the interest in Kulturwissenschaft shown in the years around 1900 by German-speaking scholars such as Aby Warburg, whose work had much greater historical depth. The traditions of cultural studies and Kulturwissenschaft are so far apart that a German introduction to cultural studies was forced to use the English term in its title in order to avoid misunderstanding (Lutter and Reisenleitner, 1998).

\section{THE MIDDLE CIRCLE}

The middle circle consists of autonomous disciplines in the social sciences: anthropology, ethnology, sociology, politics and geography, all of which have experienced what is sometimes called a "historical turn" in the sense that a substantial minority of scholars in those disciplines now work on past centuries.

Over the last thirty years or so, many cultural historians, like some classicists and archaeologists, have discovered that the study of anthropology can help them understand their own subject, despite the danger of constructing a general model of "primitive society" and then trying to fit ancient Greeks or early medieval Europeans into it. After all, the anthropologists were pioneers in the study of "cultures" in the plural and in a broad sense of the term. Scholars in neighbouring disciplines have been attracted by the centrality of culture in anthropology -even if some anthropologists are now trying to liberate themselves from the concept (Fox and King, 2002)- and also by the broad definition of culture that anthropologists employ. One might even say that the language of anthropology has become a kind of lingua franca in the humanities, particularly the language of Clifford Geertz, including his much-quoted definition of culture: "Believing, with Max Weber, that man is an animal suspended in webs of significance he himself has spun, I take culture to be those webs" (Geertz, 1973: 5). In other words, "culture" has expanded to include not only the arts and elites but the attitudes and values of everyone and their expression or embodiment in everyday artefacts and practices.

Conversely, a substantial number of anthropologists, including some of the leading figures in the discipline (Geertz, 1980; Sahlins, 1985) have been writing about the past. In contrast to the middle of the twentieth century, when "fieldwork" defined the discipline, "historical anthropology" has become respectable. The old concern with structures and functions has been replaced, or at least supplemented with an interest in processes of change, including change over the long term.

A close neighbour of anthropology is the discipline that used to be known as "folklore" or Volkskunde and has generally been renamed "ethnology" or the study of "popular traditions". It is effectively anthropology practiced by scholars from inside the culture rather than outside and its links with cultural history have traditionally been strong. Indeed, some classic works in the field, from Caro Baroja (1965) to Frykman and Löfgren (1987), might equally well be described as ethnology, historical anthropology or cultural history.

On the frontier between anthropology and sociology stood Pierre Bourdieu, whose ideas have inspired cultural historians more than anyone apart from Geertz: the idea of distinction, the idea of the habitus (borrowed from Thomas Aquinas via the art historian Erwin Panofsky), the idea of cultural capital, the idea of a cultural "field" (champ), and so on (Bourdieu, 1979, 1992).

Other sociologists have also been moving in the direction of cultural history, thus returning to the tradition of Max Weber. Historical sociology has long flourished and includes contemporary classics such as The Sources of Social Power (Mann, 1986-93), although studies of this kind have tended to concentrate on "hard" economic, social and political structures and their transformations over the long term rather than on "soft" topics such as culture. The "cultural turn" in sociology is relatively recent. However, it is gathering force, especially in the United States (Alexander, 2003; Friedland and Mohr, 2004). Cultural historians, long accustomed to looking to anthropology for ideas, are likely to find this group of cultural sociologists to be inspiring.

Economists, on the other hand, have made no cultural turn, although some economic historians have been moving in this direction, shifting their attention from production to consumption and explaining changes in consumption patterns by changes in the culture. Like their colleagues in departments of economics, members of departments of politics, "political science" or international relations have also tended to resist cultural approaches. As in the case of economics, the dominant trend in political studies remains Rational Choice Theory, which appears impervious to cultural difference. However, there are some signs of change, some evidence of dissatisfaction with the application to the rest of the world of 
models of political behaviour that are derived from the West (Chabal and Daloz, 2006).

Indeed, we are now witnessing a revival or "reinvention" of the tradition, already established in the USA in the 1950s, of studies of "political culture", which now range from the Baltic to Panama (Pettai, 2007; Pérez, 2011; Goldfarb, 2012). One indicator of change was the conversion of a leading American political scientist, the late Samuel P. Huntington, to the idea of a "clash of civilizations", in an essay that has been influential despite (or because of) its tendency to reify cultures (Huntington, 1996). Even studies of geopolitics, which have traditionally emphasized "hard" facts such as the size of armies and the amount of material resources, now find a place for "soft" or cultural factors such as images and other means of attracting rather than compelling political support (Nye, 2004).

As it happens, geographers are more concerned with both culture and history than the majority of their colleagues in the social sciences. The tradition of historical geography is an old and distinguished one, while the "cultural turn" has been particularly important in this discipline, especially in the Anglophone world. Recent studies often use the term "cultural geography" in place of the older "human geography" and focus attention on the geographical imagination (D. Gregory, 1994), "cultures of exploration" (Driver, 2000) and so on. When the cultural and historical approaches are combined, as they frequently are, it becomes difficult to distinguish between cultural geographers and cultural historians -apart from the tendency of geographers to make a greater and a more explicit use of cultural theory.

\section{THE OUTER CIRCLE}

The outer circle includes disciplines that are closer to the natural sciences than they are to the social sciences. These disciplines have often been perceived (along the lines of the famous opposition between "nature" and "culture") as virtually irrelevant to the practice of cultural history. However, in the last few years some scholars have been arguing that psychology, cognitive studies and neuroscience have something to offer students of culture, including cultural historians. Even biology is becoming relevant, since studies of animals, notably chimpanzees, suggest that they too have culture in the sense of skills that are passed from one generation to another (Wrangham et al., 1994; Lestel, 2001; Boyd and Richerson, 2005). This section focuses on the future rather than the recent past and it is necessarily speculative, but the possibility of a coming revolution in the ways in which scholars analyse culture is too important to omit.
Like sociologists, geographers and students of politics, psychologists, or at least some psychologists, have been taking the famous cultural turn, and asking whether or to what extent perception, memory or learning varies with cultures in the present ("psychological anthropology") or the past ("historical psychology"). The term "cultural psychology" (Cole, 1996) has come into use to describe what used to be variously known as "social psychology", "historical psychology" or "psychological anthropology", in other words an approach that emphasizes the differences between ways of thinking and feeling to be found in different cultures or different periods.

Psychologists have played a key role in the rise of "cognitive studies", although this label -like "cultural studies"- describes not so much a discipline as a focus for interdisciplinary research that involves different kinds of specialist, from computer scientists to neurobiologists. So far only a few scholars in the humanities have been attracted by this "cognitive revolution", or at any rate consider it relevant to their work. However, three domains of cultural history, all of them currently attracting a good deal of interest, are likely to be affected by or to enter into dialogue with cognitive studies, especially neuropsychology. These three domains are the history of the senses, the history of the emotions and the history of social or cultural memory.

Historians of the senses (for example, Classen, 1993) share a topic with scientists working on visual or auditory cognition, even if their sources and methods are very different. A few art historians have tried to close or at least to narrow the gap. Ernst Gombrich once collaborated with the psychologist Richard L. Gregory in a study of illusion in nature and art, while Gombrich's former student John Onians hopes that art historians of the future will "have the courage to be neuroarthistorians" (R.L. Gregory and Gombrich, 1973; Onians, 2007). The history of the emotions has been attracting even more attention than the history of the senses, witness not only the rising number of monographs but also the symposia on the subject (Gouk and Hills, 2005; Liliequist, 2012). However, following their sources, cultural historians have concentrated on the ways in which emotions have been represented, constructed or managed in different periods, thus placing them on a different course from neuroscientists.

Studies in the history of memory, especially of what used to be called "social memory" and is now more often described as "cultural memory", flourish even more than the history of the senses and emotions, while some psychologists have turned their attention from individual to collective memories and "cognitive ecologies". However, a gap remains between the cultural-historical and the 
neurological approaches, despite attempts to close it (Boyer and Wertsch, 2009). Most neuroscientists are concerned with the human brain in general, not with changes over time in perceptions, emotions and memories. Only if they turn their attention to cultural variation will an opportunity for a future dialogue with historians open up.

Change over time is central to the argument of one historian, Daniel Smail (2008), the author of a one-volume history of humanity in which he argues the case for a "deep cultural history" or "neurohistory". Over the very long term, in other words over hundreds of thousands of years, human brains may well have changed in crucial respects. The problem is to establish how they changed and with what consequences. In any case, most cultural historians are concerned with the last five thousand years or so, a period too short for "cognitive evolution" to be discernible.

The idea of evolution, prominent in historical studies in the later nineteenth century but generally rejected in the twentieth, appears to be making a comeback, at least in sociology, as two recent studies suggest (Runciman, 2009; Blute, 2010). W.G. Runciman argues for the importance of three forms of competitive selection in human affairs (biological, cultural and social), while Marion Blute claims that social scientists can solve some of their problems by learning from evolutionary biology. It is too early to tell whether cultural historians will respond to this challenge or take these opportunities. It is possible that a rise of what we might call "biohistory" will bring to an end the famous "cultural turn" whose demise has been predicted for more than a decade (Bonnell and Hunt, 1999). Whether or not this will be the case, the examples discussed in this section are so many powerful reminders that the map of learning is not fixed but fluid and that cultural history's closest neighbours in the future may be very different from their neighbours in the past.

\section{REFERENCES}

Akehurst, Thomas (2010) The Cultural Politics of Analytic Philosophy. Continuum, London.

Alexander, Jeffrey C. (2003) The Meanings of Social Life: a Cultural Sociology. Oxford University Press, Oxford.

Alpers, Svetlana (1983) The Art of Describing: Dutch Painting in the Seventeenth Century. University of Chicago Press, Chicago.

Bailey, Richard W. (1991) Images of English: a Cultural History of the Language. University of Michigan Press, Ann Arbor.

Baxandall, Michael (1972) Painting and Experience in FifteenthCentury Italy. Oxford University Press, Oxford.

Becher, Tony and Paul R. Trowler. (2005) Academic Tribes and Territories: intellectual enquiry and the cultures of disciplines. Open University Press, Buckingham.

Beik, William (1997) Urban Protest in Seventeenth-Century France: the culture of retribution. Cambridge University Press, Cambridge.

Belting, Hans (1990) Bild und Kult. Eine Geschichte des Bildes vor dem Zeitalter der Kunst. C. H. Beck, Munich.
Bennassar, Bartolomé and Lucile Bennassar. (1989) Les chrétiens d'Allah: l'histoire extraordinaire des rénégats. Perrin, Paris.

Blake, Casey N. (2008) Culturalist Approaches to Intellectual History. In: A Companion to American Cultural History, edited by Karen Halttunen, pp. 383-95. Blackwell, Oxford. http://dx.doi.org/10.1002/9780470691762.ch26

Blute, Marion (2010) Darwinian Sociocultural Evolution. Cambridge University Press, Cambridge.

Bonnell, Victoria E. and Lynn Hunt (editors), (1999) Beyond the Cultural Turn. University of California Press, Berkeley.

Bourdieu, Pierre (1979) Distinction: critique social du jugement. Minuit, Paris.

Bourdieu, Pierre (1992) Les règles de l'art: genèse et structure du champ littéraire. Seuil, Paris.

Boyd, Robert and Peter Richerson. (2005) The Origin and Evolution of Cultures. Oxford University Press, Oxford.

Boyer, Pascal and James V. Wertsch (editors), (2009) Memory in Mind and Culture. Cambridge University Press, Cambridge.

Bremmer, Jan and Herman Roodenburg (editors), (1991) A Cultural History of Gesture. Polity Press, Cambridge.

Bremmer, Jan and Herman Roodenburg (editors), (1997) A Cultural History of Humour. Polity Press, Cambridge.

Brunner, Otto, Werner Conze and Reinhart Koselleck (editors), (1972-97) Geschichtliche Grundbegriffe, 9 volumes. KlettCotta, Stuttgart.

Bryson, Norman, Michael Holly and Keith Moxey (editors), (1994) Visual Culture: Images and Interpretations. University Press of New England, Hanover.

Burckhardt, Jacob (1860) Die Kultur der Renaissance in Italien. Schweighauser, Basel. http://archive.org/download/diekulturderrena00burcuoft/diekulturderrena00burcuoft.pdf [accessed 11/April/2012]

Burke, Peter (2008) "Pas de culture, je vous prie, nous sommes britanniques": l'histoire culturelle en rande-Bretagne avant et apres le tournant. In: L'histoire culturelle: un "tournant mondial" dans l'historiographie?, edited by Philippe Poirier, pp.15-25. Editions Universitaires de Dijon, Dijon.

Burke, Peter (2011) The Cultural History of Intellectual Practices. In: Political Concepts and Time: new approaches to conceptual history, edited by Javier Fernández Sebastián, pp. 103-28. Cantabria University Press, Santander.

Burke, Peter and Roy Porter (editors), (1987) The Social History of Language. Cambridge University Press, Cambridge.

Caro Baroja, Julio (1965) El carnaval, análisis histórico-cultural. Taurus, Madrid.

Castillo Gómez, Antonio (editor), (2001) Historia de la cultura escrita: del Próximo Oriente Antiguo a la sociedad informatizada. Ediciones Trea, Gijón.

Chabal, Patrick and Jean-Pascal Daloz. (2006) Culture Troubles: politics and the interpretation of meaning. Hurst, London.

Chartier, Roger (1988) Cultural History: between practices and representations. Polity Press, Cambridge.

Chartier, Roger (1989) "Le monde comme representation". Annales E. S. C., 44: 1505-1520.

Chartier, Roger (1996) Culture écrite et société: l'ordre des livres, (XIVe-XVIIIe siécle). Albin Michel, Paris.

Chicangana-Bayona, Yobenj Aucardo and Francisco Alberto Ortega Martínez (editors), (2011) 200 Años de Independencias. Las culturas políticas y sus legados. Universidad Nacional de Colombia, Medellín.

Cholvy, Gérard and Yves-Marie Hilaire (1985-88) Histoire religieuse de la France contemporaine. 3 vols. Privat, Toulouse.

Classen, Constance (1993) Worlds of sense: exploring the senses in history and across cultures. Routledge, London.

Cole, Michael (1996) Cultural Psychology: a Once and Future Discipline. Harvard University Press, Cambridge MA.

Darnton, Robert (1984) The Great Cat Massacre and Other Episodes in French Cultural History. Basic Books, New York.

Davis, Natalie Z. (1982) From Popular Religion to Religious Cultures. In: Reformation Europe, edited by Steven E. 
Ozment, pp. 321-36. Center for Reformation Research, St Louis.

Dear, Peter (1995) "Cultural History of Science. An Overview with Reflections". Science, Technology and Human Values 20: 150-70. http://dx.doi.org/10.1177/016224399502000202

Driver, Felix (2000) Geography Militant: cultures of exploration and empire. Blackwell, Oxford.

Easthope, Antony (1991) Literary into Cultural Studies. Routledge, London.

Elliott, John H. (1994) Lengua e imperio en la España de Felipe $I V$. Ediciones Universidad de Salamanca, Salamanca.

Elman, Benjamin A. (2006) A Cultural History of Modern Science in China. Harvard University Press, Cambridge MA.

Elsner, Jaś and Roger Cardinal (editors), (1994) The Cultures of Collecting. Reaktion Books, London.

Elsner, Jaś and Joan-Pau Rubiés (editors), (1999) Voyages and Visions: Towards a Cultural History of Travel. Reaktion Books, London.

Fabian, Johannes (1986) Language and Colonial Power: the appropriation of Swahili in the former Belgian Congo, 18801938. Cambridge University Press, Cambridge.

Fernández Sebastián, Javier (2011) Political Concepts and Time: new approaches to conceptual history. Cantabria University Press, Santander.

Fishman, Joshua A. (1965) "Who Speaks What Language to Whom and When?'. La Linguistique: 67-88.

Flor, Fernando R. de la (2009) Imago: la cultura visual y figurative del barrocco. Abada, Madrid.

Foucault, Michel (1984a) Le souci de soi. Gallimard, Paris.

Foucault, Michel (1984b) L'usage des plaisirs. Gallimard, Paris.

Fox, Richard G. and Barbara J. King (editors), (2002) Anthropology Beyond Culture. Berg, Oxford.

Freeman, Joanne B. (2008) Political History and the Tool of Culture. In: A Companion to American Cultural History, edited by Karen Halttunen, pp. 416-24. Blackwell, Oxford. http://dx.doi.org/10.1002/9780470691762.ch29

Friedland, Roger, and John Mohr (editors), (2004) Cultural Sociology in Practice. Cambridge University Press, Cambridge.

Frykman, Jonas and Orvar Löfgren (1987) [1979] Culture Builders: A Historical Anthropology of Middle-Class Life. Translated by Alan Crozier. Rutgers University Press, New Brunswick NJ

García Bourrellier, Rocío and Jesús M. Usunáriz (editors), (2006) Aportaciones a la historia social del lenguaje: España, siglos XIV-XVIII. Iberoamericana, Madrid.

Geertz, Clifford (1973) The Interpretation of Cultures. Basic Books, New York.

Geertz, Clifford (1980) Negara: the theatre state in nineteenthcentury Bali. Princeton University Press, Princeton.

Gibson, Mark (2009) Culture and Power: a history of cultural studies. Berg, Oxford.

Glickman, Lawrence B. (2008) The Impact of the Culture Concept on Social History. In: A Companion to American Cultural History, edited by Karen Halttunen, pp. 396-405. Blackwell, Oxford. http://dx.doi.org/10.1002/978047069 1762.ch 27

Goldfarb, Jeffrey C. (2012) Reinventing Political Culture. Polity Press, Cambridge.

Gouk, Penelope and Helen Hills (editors), (2005) Representing Emotions. Ashgate, Aldershot.

Greenblatt, Stephen, Ines Županov, Reinhard Meyer-Kalkus, Heike Paul, Pál Nyíri and Friederike Pannewick (2010) Cultural Mobility: a manifesto. Cambridge University Press, Cambridge.

Gregory, Derek (1994) Geographical Imaginations. Blackwell, Oxford.

Gregory, Richard L. and Ernst H. Gombrich (editors), (1973) Illusion in Nature and Art. Duckworth, London.

Gruzinski, Serge (1988) La colonisation de l'imaginaire: sociétés indigenes et occidentalisation dans la Mexique espagnol. Gallimard, Paris.

Hoock, Holger (2003) The King's Artists: the Royal Academy of Arts and the Politics of British Culture, 1760-1840. Clarendon Press, Oxford.
Higashibaba, Ikuo (2001) Christianity in Early Modern Japan: Kirishitan belief and practice. Brill, Leiden.

Hodder, Ian (1986) Reading the Past. Cambridge University Press, Cambridge.

Huizinga, Johan (1929) De taak der cultuurgeschiedenis. Reprinted in Huizinga, De taak der cultuurgeschiedenis, edited by W. E. Krul, pp. 72-134. Historische Uitgeverij, Groningen, 1995.

Hunt, Lynn (1984) Politics, Culture and Class in the French Revolution. University of California Press, Berkeley.

Hunt, Lynn (editor), (1989) The New Cultural History. University of California Press, Berkeley.

Huntington, Samuel P. (1996) The Clash of Civilizations and the Remaking of World Order. Simon and Schuster, New York.

Infantes, Victor, François Lopez and Jean-François Botrel (editors), (2003) Historia de la edición y de la lectura en España, 1472-1914. Fundación Germán Sánchez Ruipérez, Madrid.

Irimia, Mihaela and Dragoș Ivana (editors), (2009) Literary into Cultural History, Institutul Cultural Român, Bucharest.

Jouhaud, Christian (2000) Les pouvoirs de la literature: histoire d'un paradoxe. Gallimard, Paris.

Kavanagh, Thomas M. (1993) Enlightenment and the Shadows of Chance: the novel and the culture of gambling in eighteenth-century France. Johns Hopkins University Press, Baltimore.

Klein, Lawrence E. (1994) Shaftesbury and the Culture of Politeness. Moral Discourse and Cultural Politics in Early Eighteenth-Century England. Cambridge University Press, Cambridge. http://dx.doi.org/10.1017/CBO9780511659973

Lestel, Dominque (2001) Les origines animales de la culture. Seuil, Paris.

Liliequist, Jonas (editor), (2012) A History of Emotions, 12001800. Pickering and Chatto, London.

Lutter, Christina and Markus Reisenleitner. (1998) Cultural Studies: eine Einführung. Loecker Erhard, Vienna.

MacKenzie, Donald F. (1986) Bibliography and the Sociology of Texts. British Library, London.

Mann, Michael (1986-93). The Sources of Social Power, 2 vols. Cambridge University Press, Cambridge.

Martin, Henri-Jean (1999) [1969] Livre, pouvoirs et société à Paris au XVIIe siècle, 1598-1701, 3rd edition. Droz, Geneva.

Mergel, Thomas (2002) Parlamentarische Kultur in der Weimarer Republik. Droste, Düsseldorf.

Mergel, Thomas and Thomas Welskopp (editors), (1997) Geschichte zwischen Kultur und Gesellschaft. C. H. Beck, Munich.

Mösslang, Markus and Torsten Riotte (editors), (2008) The Diplomat's World: the cultural history of diplomacy, 18151914. Oxford University Press, Oxford.

Morris, Ian (2000) Archaeology as Cultural History. Words and Things in Iron Age Greece. Blackwell, Oxford.

Nye, Joseph S. (2004) Soft Power: The Means to Success in World Politics. Public Affairs, New York.

Onians, John (2007) Neuroarthistory. Yale University Press, New Haven.

Pérez, Orlando J. (2011) Political Culture in Panama. Palgrave Macmillan, New York.

Petrucci, Armando (1986) La scrittura. Ideologia e rappresentazione. Einaudi, Torino.

Pettai, Vello (2007) Studying Political Culture in Post-Communist Europe. In: Political Culture: values and identities in the Baltic Sea Region, edited by Mai-Brith Schartau, Sten Berglund and Bernd Henningsen, pp.83-96. Berliner Wissenschafts Verlag, Berlin.

Poirrier, Philippe (2000) L'État et la culture en France au XXe siécle. Librairie Générale Française, Paris.

Renfrew, Colin (1987) Archaeology and Language: the puzzle of Indo-European origins. Cape, London.

Renfrew, Colin, and Ezra B. W. Zubrow (editors) (1994) The Ancient Mind: Elements of Cognitive Archaeology. Cambridge University Press, Cambridge.

Rioux, Jean-Pierre and Jean-François Sirinelli (editors), (199798) Histoire Culturelle de la France, 4 volumes. Seuil, Paris. 
Roosen, William (1980) "Early Modern Diplomatic Ceremonial: A Systems Approach". The Journal of Modern History, 52: 452-476. http://dx.doi.org/10.1086/242147

Runciman, W. G. (2009) The Theory of Cultural and Social Selection. Cambridge University Press, Cambridge.

Sahlins, Marshall (1985) Islands of History. University of Chicago Press, Chicago.

Schmidt, Leigh E. (2008) Religious History and the Cultural Turn. In: A Companion to American Cultural History, edited by Karen Halttunen, pp. 406-15. Blackwell, Oxford. http:// dx.doi.org/10.1002/9780470691762.ch28

Schorske, Carl E. (1979) Fin-de-Siecle Vienna: Politics and Culture. Cambridge University Press, Cambridge.

Sewell, William H. (2005) Logics of History: Social Theory and Social Transformation. University of Chicago Press, Chicago.

Shapin, Steven (1994) A Social History of Truth: Civility and Science in Seventeenth-Century England. University of Chicago Press, Chicago.

Sharpe, Kevin M. (1987) Criticism and Compliment. The Politics of Literature in the England of Charles I. Cambridge University press, Cambridge.

Smail, Daniel L. (2008) On Deep History and the Brain. University of California Press, Berkeley.

Snyder, Jon R. (2009) Dissimulation and the Culture of Secrecy in Early Modern Europe. University of California Press, Berkeley.
Stewart, Andrew (1997) Art, Desire and the Body in Ancient Greece. Cambridge University Press, Cambridge.

Vainfas, Ronaldo (1995) A Heresia dos Indios: catolicismo e rebeldia no Brasil colonial. Companhia das Letras, São Paulo.

Vincent, David (1998) The Culture of Secrecy. Britain, 18321998. Oxford University Press, Oxford.

Ware, Caroline F. (editor), (1940) The Cultural Approach to History. Edited for the American Historical Association, Columbia University Press, New York.

Warnke, Martin (1992) Politische Landschaft: zur Kunstgeschichte der Natur. Hanser, Munich.

Winkler, John J. (1990) The Constraints of Desire: the anthropology of sex and gender in ancient Greece. Routledge, London.

Winter, Jay (1995) Sites of Memory, Sites of Mourning. The Great War in European Cultural History. Cambridge University Press, Cambridge.

Woodfield, Richard (2001) Art History as Cultural History. $\mathrm{G}+\mathrm{B}$ Arts International, Amsterdam.

Wormald, Patrick (1999) Legal Culture in the Early Medieval West. Continuum, London.

Wrangham, Richard W., W.C. McGrew, Frans B.M. de Waal and Paul G. Heltne (editors), (1994) Chimpanzee Cultures. Harvard University Press, Cambridge, MA.

Zanker, Paul (1987) Augustus und die Macht der Bilder. C.H. Beck, Munich. 